University of Wollongong

Research Online

Faculty of Law - Papers (Archive)

Faculty of Business and Law

January 2011

\title{
Building future sustainability and democratic practices: The role of adult education in post-conflict communities
}

Georgia Lysaght

University of Wollongong, georgial@uow.edu.au

Peter Kell

The Hong Kong Institute of Education

Follow this and additional works at: https://ro.uow.edu.au/lawpapers

Part of the Law Commons

\section{Recommended Citation}

Lysaght, Georgia and Kell, Peter: Building future sustainability and democratic practices: The role of adult education in post-conflict communities 2011, 152-163.

https://ro.uow.edu.au/lawpapers/103

Research Online is the open access institutional repository for the University of Wollongong. For further information contact the UOW Library: research-pubs@uow.edu.au 


\title{
Building future sustainability and democratic practices: The role of adult education in post-conflict communities
}

\author{
Abstract \\ This paper documents and analyses a range of literature and policy statements that identifies issues and \\ looks at the role which adult education plays in building communities and peace in post-conflict states. \\ This paper explores and documents these developments in countries in close proximity to Australia which \\ have been viewed by the former Australian government as constituting an 'arc of instability'. This is a term \\ which will be critically discussed in the paper for the way in which it positions the nations of the Pacific \\ and Australia's foreign policy as well as its aid and development policy. This paper reviews existing \\ orthodox approaches to the region and development and discusses the criticisms that have been levelled \\ at the status quo

\section{Keywords} \\ sustainability, adult, education, post, role, conflict, practices, communities, democratic, building, future \\ Disciplines \\ Law

\section{Publication Details} \\ G. Lysaght \& P. Kell, 'Building future sustainability and democratic practices: The role of adult education in \\ post-conflict communities' (2011) 9 (1-2) International Journal of Training Research 152-163.
}




\section{Building future sustainability and democratic practices: The role of adult education in post-conflict communities}

\section{GeORGIA LysAght}

Research Fellow, Centre for Transnational Crime Prevention, University of Wollongong, NSW, Australia

\section{Peter Kell}

Centre for Lifelong Learning Research and Development, Hong Kong Institute of Education, Hong Kong

\section{ABSTRACT}

This paper documents and analyses a range of literature and policy statements that identifies issues and looks at the role which adult education plays in building communities and peace in post-conflict states. This paper explores and documents these developments in countries in close proximity to Australia which have been viewed by the former Australian government as constituting an 'arc of instability. This is a term which will be critically discussed in the paper for the way in which it positions the nations of the Pacific and Australia's foreign policy as well as its aid and development policy. This paper reviews existing orthodox approaches to the region and development and discusses the criticisms that have been levelled at the status quo.

Keywords: post-conflict, arc of instability, adult education, foreign assistance

\section{INTRODUCTION}

F rom the middle of the 20th century, the number of sovereign nations increased
markedly as a result of decolonisation and the retraction of the United Kingdom as the global hegemony. However, many of these newly independent states faced a new set of challenges, as the former colonial powers had invested little into creating a solid infrastructure and fostering a national system of governance. Furthermore, many of the geographical boundaries drawn up in the global South by the Northern colonists in the decades and centuries prior, forced the
Indigenous peoples into states and regimes to which they had not consented. Subsequently, contests over power, natural resources, capital, and land characterised the decolonised political, economic and social landscape of the South. Some of these countries such as New Guinea, the Solomon Islands and East Timor have been strongly influenced by Australia. In the case of New Guinea it was administered under a League of Nations and United Nations mandate. Many of the countries have been perceived as unstable and categorised as rogue states. In the rhetoric of the global war on terrorism, these nations have 
been seen as vulnerable to penetration from terrorist organisations.

It is for these reasons that South Asia and the South Western Pacific is of relevance as it has been 'a region [that] has the ignominious status of being one of the most conflict-ridden heavily militarised and potentially volatile regions of the world' (ASPBAE, 2009, p. 8). Then Australian Prime Minister, Kevin Rudd also signalled the Asia Pacific as an area of instability (or so-called 'arc of instability', citing the areas of particular concern in each state:

... Jema'ah Islamiya's continued operations in the Indonesian archipelago; police and military crises in East Timor; continuing challenges to political stability in Papua New Guinea; ethnic violence in Vanuatu; the implosion of law and order in the Solomon Islands; a series of coup d'etat in Fiji; a constitutional crisis combined with unprecedented street violence in Tonga; and Nauru, the region's first properly defined failed state having also become a centre for international money laundering (Rudd 2007).

The rehabilitation and reconstruction of postconflict states therefore requires strategies that are specific to the particularities of a post-conflict context.

While education is often a nominal theme of reconstruction and rehabilitation, adult education is often overlooked, or considered useful only in the creation of a skills based labour market, whereby knowledge only has value when it is tied to capital. This way of conceptualising adult education has stemmed largely from external actors which have played a role in the rehabilitation and reconstruction of the Southern states, in particular the International Financial Institutions (IFIs) - the World Bank (WB) and International Monetary Fund (IMF) - UNESCO, and a plethora of Big International Non-Government Organisations (BINGOs). However, there are alternative approaches to the 'international' solution to adult education, and these are encapsulat- ed in the works of education revolutionaries such as Paulo Freire. The approach of Freire and others is neither a 'grass roots' nor a neoliberal institutional model. Instead, it focuses upon the organic reformation of the education system through the direct participation of the local actors. However, it seeks to reform the system in a way that does not recreate the exploitative conditions of production and consumption. Likewise, it does not inherently reject bourgeoisie ideas or notions for the sake of it, rather the approach extrapolates the most conducive ideologies from all strata of society to create an emancipatory education system suited to each social, cultural, political, economic historical context. This paper will set up a framework that critically analyses the former approach, so as to go into an in-depth discussion on the latter approach in the second part of the paper.

\section{DEFINING POST-CONFLICT ENVIRONMENTS}

The intricacies of addressing adult education and social development as a whole in conflict or post-conflict situations are quite specific. In order to position some parameters for the ensuing discussion it is important to first clarify the notions of 'conflict', and 'post-conflict'. The Asia South Pacific Association for Basic Adult Education (ASPBAE, formerly the The Asian South Pacific Bureau of Adult Education) states that it is important to distinguish between violent and non-violent conflict and maintains that 'violent conflict is destructive' (ASPBAE, 2009, p. 12). The conflict that occurs in the Asia Pacific region generally falls under the classification of violent conflict. ASPBAE contends that conflict is caused by a mix of structural, political, economic/social and cultural and perceptual factors (ASPBAE, 2009, p. 13) and that there are four distinct categories of conflicts, namely: 1) Intractable conflicts; 2) Protracted social conflicts; 3) International-social conflicts; and 4) Complex political emergency (ASPBAE, 2009, p. 16). Table 1 illustrates the nature of each of these distinguishable types of conflicts. 
TABLE 1: ASPBAE's CATEgories of CONFLICT

$\begin{array}{ll}\text { Conflict type } & \text { Characteristics } \\ \text { Intractable conflict } & \begin{array}{l}\text { Conflict situations which are difficult to influence or resolve, with the parties } \\ \text { to the conflict stubbornly resisting solutions } \\ \text { Characterised by prolonged and often violent struggle by communal groups } \\ \text { for such fundamental needs as security, recognition and acceptance, fair } \\ \text { access to political institutions and economic participation }\end{array} \\ \text { International social conflict } & \begin{array}{l}\text { Conflicts that are neither purely interstate nor purely domestic conflicts, but } \\ \text { fall somewhere between the two } \\ \text { Complex political emergency }\end{array} \\ \text { Has evolved as the key category for grasping the complex nature of most con } \\ \text { temporary conflict, is an integral concept referring to conflicts which are multi- } \\ \text { dimension with large-scale human rights abuses and profound human suffering }\end{array}$

Source: ASPBAE, p. 16

In the Asia Pacific, a mix of these types of conflicts occurs: for example, in East Timor the struggle and violence during the independence period was characterised specifically by ethnic factors. According to ASPBAE, Sri Lanka is an example of a complex political emergency (ASPBAE, 2009, p. 16).

It is also necessary to clarify the terms 'postconflict' and 'post-conflict state'. The UNDP defines 'post-conflict states' as states that 'have recently emerged from a period of prolonged violent conflict. The result of such violence is, typically, a seriously compromised economic, social and physical infrastructure' (UNDP 2005, p. 2). Thus the setting in which the rehabilitation of education systems and other types of social infrastructure may occur entails its own unique set of characteristics. Yet, the conditions and outcomes of post-conflict states are by no means static. The UNDP states that there are numerous post-conflict environments:

At one extreme are countries where the violence was so overwhelming that the state essentially collapsed. Countries such as Liberia, Bosnia-Herzegovina, Democratic Republic of Congo, Sierra Leone, and Somalia would seem to belong here. At the other extreme are countries such as Guatemala, Sri Lanka, and the Former Yugoslav Republic of Macedonia that have emerged with their political and economic structures (UNDP 2005, pp. 2-3).
It is important to note here that the phrase 'post-conflict state/s' rather than 'failed state/s' is quite deliberate, as it allows for analysis to be more expansive. In terms of 'failed states', the Asia-Pacific focus would limit the study to only Nauru, which is the sole state in the region that is formally recognised as a 'failed state' (BBC Monitoring Asia Pacific 2007). East Timor for instance cannot be considered a 'failed state' as Atul Khare, special representative of the UN secretary general for East Timor deemed it 'an emerging democracy [and], too young, to be a failure' (Asian Political News 2007). Interestingly, there are new arguments emerging that claim parts of remote Australia contain the characteristics of a 'failed state'. In particular, a group called Desert Knowledge Australia, which is comprised of politicians, academics and ministers, released a report which stated that 'the characteristics of failed states - poverty, violence, basic services and a lack of government legitimacy - are all realities in more distant parts of the country' ( $A B C$ Radio Australia 2008). Based on the understanding of the aforementioned definition of conflict, we shall now turn to address the intricacies of postconflict situations.

\section{CONTEXT OF POST-CONFLICT ENVIRONMENTS}

Whether through specific intentions or incidental situations, the education system in post-conflict states is prone to partial or complete collapse. 
Conflict affects both the physical facets of the education system, and the people that are part of it. During conflict, the physical infrastructure of the state or region involved is immediately vulnerable. For example, the Indonesian military's 'Scorched Earth' policy in 1999 targeted, amongst other infrastructure, schools, the university and colleges. Consequently, between 1999 and 2000 the education system ceased to exist altogether, and it is estimated that around 95\% of school buildings in East Timor were demolished by the Indonesian military. Primary, secondary and tertiary education facilities are often prone to high degrees of physical damage during conflict as they may be used for barracks, by military or non-military forces, or for safety by civilian groups attempting to protect themselves from the conflict. Schools and colleges may also be utilised as make-shift refuge shelters during the conflict or as medical centres. Such facilities and building are subject to looting either by military forces or even civilians, as there is usually a general state of lawlessness during situations of intense conflict.

The relationship that staff and students have with one another and their relationship with the education system in general may be dramatically altered in the post-conflict rehabilitative stage to what it was prior to the conflict. This is due to a number of factors, and the possibility of the changes that may occur in this relationship is non-exhaustive. For example, tertiary institutions and colleges may be a target of military or aggressive forces, as the students themselves often play an active leading role in the community's struggle for change in the pre-conflict era. In this case, they are targeted as they are deemed by the enemy as a threat. However, in other situations, children from primary and secondary schools are deemed assets rather than threats and may be coerced into being active participants of the conflict. In Burma/Myanmar for example a child recruit has given an account where:

... government soldiers surrounded his school and arrested 40 to 50 youths between 15 and
17 years of age: 'Our teachers all ran away in fear,' says the recruit, quoted in the Burma/ Myanmar case study. 'We were all terrified. I didn't know what was going on and they didn't explain anything to us (Welles 1997).

Much literature also exists in sub-Saharan Africa where both boys and girls are forcibly removed from schools and communities and recruited by rebel forces. In the aftermath of this situation, children often cannot return to their original communities let alone return to schools. Bretherton comments that:

Social as well as physical structures will be in need of repair and programmes will have to build trust. Participants might come from opposing sides of the conflict. In Sierra Leone, it is 'difficult if not impossible, to find a child that has not seen or have been part of the atrocities committed in the war, or who does not have relatives who have been affected (Pesonen in Bretherton, Weston \& Zbar 2003, p. 223).

Thus it cannot be assumed that students or educators were united against a common enemy for the duration of the conflict. Such circumstances bear relevance in terms of the social divisions that may arise in post-conflict educational settings, and may have implications for education programmes that would not be problematic in many other non-conflict settings. On even the most basic and practical level post-conflict specific problems may arise. Bretherton warns that activities that are fun and ice-breakers in a peaceful context may suddenly take on a deeper aspect in a war zone. For example, a blindfold trust game might evoke images of checkpoint searches and being taken hostage' (Bretherton, Weston \& Zbar 2003, p. 223).

Teachers and educational facilitators too are often affected by conflict and their relationship with the students and the education system in general may be altered dramatically in the wake of conflict. In East Timor, a vacuum has occurred in the number of qualified teachers, as before the 
conflict, the overwhelming proportion of teachers were Indonesian rather than Timorese. This flight of the professional class is highly problematic, and will be discussed in greater detail later in the paper. Suffice to say here that circumstances exist where there is a severe lack of teachers after a conflict because often individuals with skills will flee from a conflict situation to seek better paid and more secure work in other countries or regions. Teachers also have a dual role as they must first come to terms with the new education system, and second actively encourage the return of students at the primary, secondary and tertiary levels. A head teacher at a school in Dili illustrated the complexity of this situation, saying that:

Everything was destroyed, schools were burned, all the furniture, but we supported each other. We asked children to come to school rather than just hang around. We talked with the parents who lived near the school. We knew we had to start the school, even though we had nothing. We started with language teaching and we even tried to give some teacher training. We did not get any salary. Some parents helped us and we tried to start other schools until the transitional authority could start. We asked for support from the priest and the church. We also received support from CNRT and UNICEF (UNICEF 2002).

Thus, the re-establishment of the education system in a post-conflict setting must take into account not only the type of education and training that should take place, but also the psychological needs of the students (Kline and Mone 2003, p. 332) and staff. This topic is particularly pertinent in Australia in regard to the so-called arc of instability. During the Howard years the term was utilized to denote a security focus, rather than a defined area to which Australia might have considered itself 'responsible'. Former Prime Minister Rudd's response to the socalled 'arc' was not quite the 'responsible to' approach. Nevertheless he has argued that military and non-military support for the region is in the national interest as to allow a series of failed states to exist in the region would be far more costly to Australia. Former Prime Minister Rudd proposed a development/security partnership approach which would deal with the areas of primary education provisions, primary healthcare provisions, infrastructure development, youth unemployment (particularly males) reductions, microfinance provisions, good governance reforms, university development for vocational purposes, and security/police issues (Rudd 2007). This is a more responsive approach to that of the previous Liberal government. It is well documented that instability is cyclical, that is, economic, social, political problems may result in violent conditions which, in turn, deteriorate the first three spheres mentioned. It is likely that Australia will be an influence in the so-called 'arc' that will not only provide security but will help to stabilise these spheres to improve local situations. This will contribute to the creation of politico-economic conditions that are more conducive to sustainable growth and development. However there is also a need for a recognition of the role of larger regional powers that have historically occupied a prominent role in the Asia Pacific region.

\section{REHABILITATION AND RECONSTRUCTION}

The notion of development in the rehabilitation and reconstruction stage is somewhat problematic. Development is often only recognised on indexes that are linked to economic growth but not development in general. Some communities would argue that development would not constitute a reproduction of the exploitative conditions under which they work. Boughton contends that:

Development debates often focus, therefore, around such questions as development for what, and for whom? Development theorists help communities, societies and nations address a fundamental question: What kind of a society do we wish to become and through what means can we get there? (Boughton 2008, p. 119).

Thus the inclusion of education is central to many development strategies, however, it is pri- 
mary education that is often prioritised and considered important in lifting literacy rates as well as building attendance levels. However, this may not be the case in many post conflict zones, as different sections of the population may have been affected in different ways.

In Somaliland for instance, development through establishing primary education does not encapsulate all members of the population that should be the recipients. The Institute for Practical Research and Training (IPRT) states that, a whole generation in Somaliland missed out on basic levels of education due to the war. This section of the population has been deemed to 'represent a disenfranchised and destabilizing element in the society' (IPRT 1998). Thus, in order to execute a sustainable development strategy adult education and vocational training directed at this section of the population was of pivotal importance. The various actors involved in the rehabilitation of institutions and systems must keep in mind that such process occurs alongside the aftermath of a war. Kline and Mone state that populations emerging from war experience trauma due to long periods or permanent separation from family and community members, death of family and community members, or the dispossession of homes and other physical possessions. In terms of formulating an appropriate education system, the actors involved must bear in mind that the 'challenge is not simply to survive a single catastrophe and then repair and heal and resume routine life, but also to adjust to ongoing stress with episodic occurrences of acute threat, while trying to maintain everyday existence' (Kline and Mone 2003, p. 323). Kline and Mone's study shows adolescents that were observed to be coping well exhibited three primary characteristics, namely: able to maintain an intact sense of purpose, effectively control traumatic memories and successfully protect oneself against destructive isolation (Kline and Mone, 2003, p. 324).

\section{VIEW ON IMPORTANCE OF EDUCATION}

Youngman discusses the assumptions international institutions often hold in promoting adult edu- cation and the misconceptions of cause and effect these often involve. UNESCO for example states that adult education is:

a powerful concept for fostering ecologically sustainable development, for promoting democracy, justice, gender equity, and scientific, social and economic development, and for building a world in which violent conflict is replaced by dialogue and a culture based on justice (UNESCO cited in Youngman 2000, p. 2).

However, Youngman is critical of this approach, and argues that:

This kind of general statement on adult education's role is based on the expectation that adult education programmes can address specific development tasks. For example, it is assumed that agricultural extension programmes can improve agricultural production and food security, thereby reducing malnutrition; that skills training can strengthen income-generating projects and help to eradicate poverty; that literacy classes can increase women's involvement in public affairs and extend democratic participation. It is expected that in such ways adult education programmes can contribute to the economic, political and social dimensions of development (Youngman 2000, p. 2).

Finger and Asún too, highlight the problematic nature of UNESCO's approach to aid, education and development. In particular, they point out that the promotion of 'continuing education' does not necessarily result in an empowered population:

Again, education permanente is not very sound intellectually; it simply echoes the modernist credo that the sum of enlightened individuals will automatically lead to a better society. In this sense, UNESCO's philosophy of adult education is not much different from the Western idea of education in general (Finger and Asún 2001, p. 27).

Another example relates to the assumption that the use of local / so-called tribal / mother 
language (or dialects) will empower minority / peripheral groups. However, this is not necessarily the case. Degu's study exemplifies this point in relation to language policy in apartheid South Africa. The English language was suppressed to promote the use of Afrikaans, and tribal languages of Setwwana, Sesoto, Khosa and Zulu. The intent behind this particular policy was not to empower the various so-called tribal groups in South Africa but rather a 'divide-and-rule policy'. Degu concludes that 'the introduction of the mother tongue in education is not always intended to develop local cultures and to respect the rights of the communities to use their languages' (Degu 2005, p. 133).

Gray-Cowan argues that there is a broad consensus that the implementation of education in developing countries will inevitably foster sustainable economic growth (Gray-Cowan cited in Degu 2005). While there is a degree of validity in such an assumption, it must be understood that:

There is no evidence that education will lead automatically to economic development. Only if education becomes part of a closely integrated and comprehensive plan for development, involving both the government and the private sector of the economy and including all levels of society, can it play its full part (Gray-Cowan cited in Degu 2005, p. 140).

In other words, as Gray-Cowan asserts, represent a disenfranchised and destabilizing element in the society if education is pursued as an end in itself, it may well retard development, since political instability may result from the failure of the national economy to provide the expected by its educated citizens' (Gray-Cowan cited in Degu 2005, p. 140).

This is a lesson that the international development community in particular should keep in mind. Easterly also demonstrates that it cannot be assumed that foreign aid will necessarily improve the standard of living on a pro rata basis. His study states that aid agencies have shown that to increase the per annum income of a poor per- son by $\$ 3.65$ the cost is in the vicinity of $\$ 3521$ in aid (Easterly 2002, p. 1). Thus, in order to effectively implement aid and aid-related programs it is essential that the relevant actors do not continue along the assumption that education necessarily equals development.

However, on the basis that the aforementioned assumption is challenged, education in post-conflict zones can be a force for building democracy and peace. Adult education can have a positive impact on development, as demonstrated by Boughton. In Tanzania and Mozambique for example, Boughton argues that the increase in adult literacy as a result of adult education programs helped to empower the adult population, who thus had a greater say in how their countries were to develop. He also cites Central and South America where the impact of literacy educations have been similar (Boughton 2008). Similarly, peace education is a component that may be built into the school curriculum or can be implemented in what Bretherton terms a 'whole school approach' (Bretherton, Weston and Zbar 2003). Both approaches have had some success in postconflict zones and the main issues that are dealt with as part of the program are (Bretherton, Weston and Zbar 2003, p. 227):

- dealing with trauma

- communication

- conflict management

- human rights and democracy

While there is a lot of focus upon primary and secondary education, adult education is an area which is often passed over in post-conflict zones as the importance of the former two are often privileged. With the lack of state funds which commonly occurs after a war, development agencies and governments often look towards establishing what is considered the essentials. Adult education is generally considered desirable rather than essential, thus it is often not given much importance in the rehabilitation and reconstruction stage. However, in his address to the International Council of Adult Education's World 
Congress, Julius Nyere, the first President of Tanzania stressed the important role that adult education played in development:

But Man can only liberate or develop himself. He cannot be liberated or developed by another. For Man makes himself...The expansion of his own consciousness, and therefore his power over himself, his environment, and his society, must therefore ultimately be what we mean by development...Adult education has to be directed at helping men to develop themselves...(and) in particular...to decide for themselves - in cooperation - what development is. (Nyere in Boughton 2008, p. 122).

Nyere's statement is demonstrative of a point made earlier in this paper - who determines what development is? And for whom should development occur? Adult education has also until recently received only limited support from the major International Financial Institutions (IFIs). Boughton contends that the decision to neglect the area of adult education was made intentionally on political grounds. Adult education programs were considered problematic by the World Bank as they were linked with Paulo Freire's notions of 'empowerment' (Boughton 2008). It is now to the assistance models of institutions of the World Bank and the like which we shall now turn.

\section{OLD TECHNICAL ASSISTANCE MODELS}

As a result of external institutional influence in post-conflict zones, there are varied approaches to the formulation and implementation of adult education programmes. Boughton divides the approach of adult education and development into two distinct trends, the first being that of the human capital approach: In order to promote development, countries must foster economic growth. The most effective way to do this is through the entry of Foreign Direct Investment (FDI) and the expansion of the private sector, both of which are reliant on various labour related skill sets. In order to attract this capital, coun- tries must ensure that their population possesses the skill sets which match the demands of the market. Thus in this context, adult education is a means to producing programs that will endow the population with the necessary skills to engage in the relevant industries and hence contribute to economic growth. Therefore, Boughton argues, this particular approach ties adult education with wage- based labour and economic development (Boughton 2008). However, there are a number of questions which arise when considering this particular development trajectory. Indeed does wage labour, which is a result of adult education and vocational training, assist the population in its struggle against poverty or does it just recreate the conditions of exploitation that occurred before the conflict? Does this really answer our question about 'development for whom?' While the rise of private enterprise may in fact contribute to the GDP, does it contribute to the overall development of that state and the population that resides within it? Does that population want to move towards a money-based system? Just because the adult population is deemed 'more educated' or 'skilled', do they receive a fair income? Who owns the enterprises for which these adults are being trained? And what proportion of the profits from the enterprise should the employees receive?

The second trend that Boughton (2008) explores is somewhat different. Rather than a top down approach, the model requires the active involvement of the whole community to formulate and direct the education programmes that it will receive. Such an approach is conducive to yielding an empowered population that plays a more active role in how the country is run, both at local and national levels (Boughton 2008). This way of thinking was originally championed by the works of Paulo Friere, and later, prominent advocates of popular education. In reality, Boughton concludes, that in real life a combination of the two models emerge, rather than one that is purely 'basist' or neoliberal (Boughton 2008). This shows that to operate well it is not 
wise to take an exclusively 'basist' or neoliberal approach. The next question that must be asked is: how do such models originate and evolve? The influence of foreign assistance and education and knowledge institutions is of prime importance when considering this topic.

\section{FOREIGN ASSISTANCE IN POST- CONFLICT ENVIRONMENTS}

The influence of external actors during the rehabilitation stage in post-conflict zones is extensive, and thus important, particularly in relation to education and adult education. In a post-conflict environment, the government of the day may not necessarily have the legitimacy or capacity to make the reinstatement of the education system a priority, nor may it possess the necessary funds. Thus, the reconstruction and rehabilitation of the education system in post-conflict zones is heavily dependent upon the foreign aid and funds, and the consolidation of a legitimate government. The provision of foreign aid and programs, whether it be through an overseas development agency (ODA), an international institution such as the World Bank, or a foreign non-government organisation can be somewhat problematic for various reasons. In brief, the programs implemented under the auspices of western institutions are inherently neo-liberal and are tied to the Washington consensus-based approach, which ties education to capital and economic indicators. Thus, post-conflict zones are generally subject to an external mode of rehabilitation of the education system which promotes western interests.

According to Carnoy (1980), international institutions have had a major impact on education policy in the developing world since the middle of the 20 th century. Indeed the international institutions succeeded in creating and reinforcing the myth that education necessarily leads to so-called development. This stems from the model described by Boughton, where it is assumed that underdevelopment in a country is attributed to its lack of economic growth, caused primarily by an unskilled labour base. Thus the remedy to the 'problem' is to train the population with 'middle' and 'high' level skills, which will subsequently result in higher rates of economic growth and thus development (Carnoy 1980). The main characteristic of this approach is that the focus is therefore on 'education and work' and primary education (Carnoy 1980). For example, the World Bank's Education website states that 'Education is key to achieving the Millennium Development Goals (MDGs) and is a powerful driver for development of individuals and society - improving health, gender equality, peace, and stability. For this reason, it is at the center of the World Bank's mission for a world free of poverty.' (World Bank 2010). The priorities of the donor institution or country from which the donations originate also have implications for the way in which the money is used. Youngman states, for example, that educational aid from Germany is directed towards technical and vocational education, but educational aid from Sweden priorities basic education. Thus because of different trends and donors, educational aid often promotes inconsistent ends (Youngman 2000). Easterly contends that such an imposition of priorities by donor states directly impinges upon the recipient country's sovereignty. It is not likely that the situation would work in the reverse however and Easterly doubts 'whether the United States would have been willing to have international agencies or foreign governments dictate its policies or institutions at any point in American history' (Easterly 2002). This illustrates not only the problematic nature of educational aid, but also the paternalistic attitude espoused by the donors.

Despite the need for radical change in this area, the problem of central planning often over-rides any improvement that may be made by the donor country. Easterly states that the problems of a central planning strategy include: 'the vast information requirements, the oversimplification to quantifiable targets as opposed to the real subjective wants, the meeting of targets without regard to relative costs and benefits, the lack of feedback 
from local practical knowledge- applied with even more force in a poor country with poor institutions and under-skilled civil service than in a rich country' (Easterly 2002). This framework, Easterly argues, results in a system that does generally not improve on its past efforts (Easterly 2002). An even more archaic approach by the international institutions is the aforementioned downsizing of the adult education sector in countries that have been subject to IMF Structural Adjustment Programs. As part of budget and fiscal austerity measure, adult education is almost always an area that suffers from severe reductions in government expenditure (Youngman 2000). With big institutions such as the World Bank, education constitutes part of an overall framework and strategy to foster development, thus a critical enquiry into its proper formulation and execution fails to occur. Thus of a 14 point system to foster development, 'Education and Knowledge Institutions' forms only one point, which is somewhat lacking in critical thinking. Former president of the World Bank, James Wolfensohn states:

All agree that the single most important key to development and to poverty alleviation is education. This must start with universal primary education for girls and boys equally, as well as an open and competitive system of secondary and tertiary education. Construction of schools, modern curricula geared to the new technological age, and the real needs of the emerging local market, and effective teacher training and supervision all contribute to successful educational programs. Adult education, literacy and lifelong learning must be combined with the fundamental recognition that education of women and girls is central to the process of development. A government must also be careful to learn lessons of practice and history from indigenous peoples and communities, so that education is not imposed from afar but benefits from relevant local, communal experience. Finally, preschool education must be given its full weight in programs. This can be a key to the development of a child, the level of education reached, and thus the eventual achievement.

In addition, I should observe that developments in science, technology, and knowledge transfer offer a unique possibility to countries to catch up with more technologically advanced societies (Wolfensohn 1999).

This uncritical approach refers to the problematic notions of continuing education, labour-based education, and the primacy of primary education. While it does note the importance of incorporating girls and women into the education system, it adopts a top-down attitude, rather than one that is participatory. Participation by the recipient country has perhaps been actively stifled by the International Financial Institutions. Easterly notes that the reports for the Poverty Reduction Strategy Papers (PRSPs) (an initiative that was designed specifically to incorporate the voices of the poorest countries in the world) were written in English in non-English speaking countries. Furthermore, there were instances where the reports were written by the IFIs rather than the country's government, so they would comply with the criteria set by the institutions (Easterly 2002).

\section{Conclusion: NeW WAYS OF THINKING}

This paper has highlighted the problems associated with developing adult education systems in post-conflict zones. While phrases such as 'partnership' and 'consultative process' are espoused by international aid agencies, international financial institutions and donor governments, the question must be asked: 'How free are developing countries to develop systems of education tailored to their own individual needs?' (Thompson cited in Youngman 2000). It appears that a radical departure needs to be taken in order to promote education systems that actively promote development for all strata of society.

Where should development practitioners and adult educators start? How might they approach 
the task of development work differently? Approaches to developing adult education in post conflict societies should consider participatory research strategies as a starting point. Participatory research has a strong tradition of being used amongst the poorest, dispossessed and exploited in societies who work in collaboration with animateurs in universities (Denzin \& Lincoln 2003). It has the advantage of avoiding 'a priori' assumptions by 'outsiders' and enables processes that empower participants and creates a sense of ownership of the processes and outcomes. The value of this research process is that it can potentially build communities that may be fragmented through a research process. This approach also has a constructivist approach where the 'lived realities' of the participants including knowledge systems, norms and values are incorporated as central to the research process.

Such an approach enables local language, culture and perspectives to be centrally located with the research and enables an anthropological and ethnographic approach that incorporates social and cultural perspectives. Critical action research may be used by practitioners in these settings because it has a:

commitment to bring together a broad social analyses: the self reflective collective self study of practice, the way language is used, organisational power in the local situation and action to improve things (Denzin and Lincoln 2003).

A participatory approach is broadly consistent with peace building strategies proposed in communities recovering from conflict as it re-establishes community networks and develops collaborative approaches to development. Importantly groups who have been disengaged from civic society in periods of conflict such as women, young people and the disabled can be reengaged through participatory processes. In reflecting on several programs in East Timor, Bougainville and the Solomons, (Boughton 2008); Durnan suggest there is also a strong commonality between the notion of social transformation proposed by development professionals and non-governmental agencies and the styles of transformations proposed by socially transformative practices in adult education. In describing what is required for community development, Durnan (2005) argues that:

Transformative peace building can be summarised as having three key aspects; mobilising the population to determine their future development pathways; addressing issues of social inequality; especially gender; and reengaging community leaders in the process of social and political transformation at the local level in the new post conflict era (Durnan 2005, p. 46).

This approach fulfils some of these functions and concurrently enables the selected communities to develop adult education projects that have the potential to rebuild social and economic infrastructures as well as promote inclusion. The possibilities for development is also maximised through approaches that are termed as 'popular education' where participants explore contradictions and dilemmas associated with the social, economic and political structures of society. Deemed a socially critical movement, popular education has been utilised by impoverished and marginalised communities. However this approach does not 'help the disadvantaged' or 'manage poverty' but has more to do with 'assisting in the struggle for a more democratic, just and egalitarian society' (Martin et al. and Thompson in Durnan 2005, p. 52). This type of methodology has strong crossover between research and learning because the proposed methodology involves participants in a collective learning experience as they explore issues and contradictions that influence their lives and their communities.

This contribution has identified the need for a futuristic research process in project development in post conflict societies which assists and promotes the participation of people, particularly women, who through the combination of war and poverty have little chance of (re)shaping their lives peacefully. The authors propose that this approach combined with popular education is a way of building connections and networks that are the foundation for peaceful communities in the future. 


\section{Reference}

ABC Radio Australia (2008) 'Remote Australia a

'Failed State", 15 September, 12:40

http://www.abc.net.au/news/stories/2008/09/15/

2364336.htm [accessed 10/10/08]

Asian Political News (2007) 'Top UN Official Says

E. Timor Fragile but not 'Failed State", 8

September 2007, nopgcit.

ASPBAE - Asia South Pacific Association for Basic and Adult Education (2009) 'Peacebuilding Kit', http://www.aspbae.org/ [accessed 10/01/09]

BBC Monitoring Asia Pacific (2007) 'Australian Opposition Sets Out Regional Foreign Policy', 5 July 2007, nopgcit.

Boughton, B (2008) 'Adult education and development' in J Athanasou (ed), Adult Education and Training, James Barlow Publishing, Sydney, pp. 119-133.

Bretherton, D, Weston, J and Zbar, V (2003) 'Peace education in a post-conflict environment: the case of Sierra Leone', Prospects, XXXIII(2), 219-230.

Carnoy, M (1980) 'International institutions and educational policy: A review of education-sector policy', Prospects, X(3), 265-266.

Denzin, NK and Lincoln, YS (2003) Strategies of Qualitative Inquiry 2nd edn, Sage, Thousand Oaks.

Durnan, D J (2005) Popular Education and Peacebuilding in Timor Leste, Master of Professional Studies with Honours, University of New England.

Easterly, W (2002) 'The Cartel of Good Intentions: Bureaucracy versus Markets in Foreign Aid', Center for Global Development, Working Paper Number 4, March.

Finger, M and Asún J M (2001) Adult Education at the Crossroads: Learning Our Way Out, Zed Books, London, New York.

Degu, WA (2005) 'Reforming Education', in G Junne and W Verkoren (eds), Postconflict Development: Meeting New Challenges, Lynne Rienner, London, pp. 129-146.

IPRT (1998) 'The First Conference on Reconstruc- tion Strategies and Challenges Beyond Rehabilitation', Hargeisa, Somaliland, 20-24 October, 1998, http://www.iprt.org/FirstConfOn Reconstruction.htm [accessed 02/10/08] Kline, PM and Mone, EM (2003) 'Coping with war: three strategies employed by adolescent citizens of Sierra Leone', Child and Adolescent Social Work Journal, 20(5), October.

Rudd, K (2007) 'Fresh ideas for future challenges: a new approach to Australia's Arc of Instability', Speech to the Lowy Institute, 5 July 2007, http://www.alp.org.au/media/0707/speloo050.p hp [accessed 20/12/08]

UNDP (2005) 'Sustaining Post-Conflict Economic Recovery: Lessons and challenges', BCPR Occasional Paper 1, http://www.undp.org/cpr/ documents/eco_recovery/Economic_Paper_12_ Dec.doc [accessed 20/02/11]

UNICEF (2002) 'Supporting girl students in East Timor: An interview with Filomena Capeda, Head teacher, Farol Primary School Dilli, Teachers Forum, November 2002, http://www.unicef.org/ teachers/forum/1102.htm [accessed 20/10/08]

Welles, M (1997) 'Child Soldiers', http://pangaea.org/ street_children/africa/armies.htm, November / December 1997. [accessed 17/12/08]

World Bank (2010) 'Education', October, http://web.worldbank.org/WBSITE/EXTERNA L/TOPICS/EXTEDUCATION/0,,contentMD K:20040939 - menuPK:282393 - pagePK:148956 - piPK:216618 theSitePK:282386,00.html [accessed 22/02/11]

Wolfensohn, J (1999) 'A Proposal for a Comprehensive Development Framework', January.

http://web.worldbank.org/WBSITE/EXTERNAL/ PROJECTS/STRATEGIES/CDF/0,,contentM DK:20072890 menuPK:140147 -pagePK:1393 01 piPK:261885 - theSitePK:140576,00.html [accessed 15/12/2008]

Youngman, F (2000) The Political Economy of Adult Education and Development, Zed Books, London, New York.

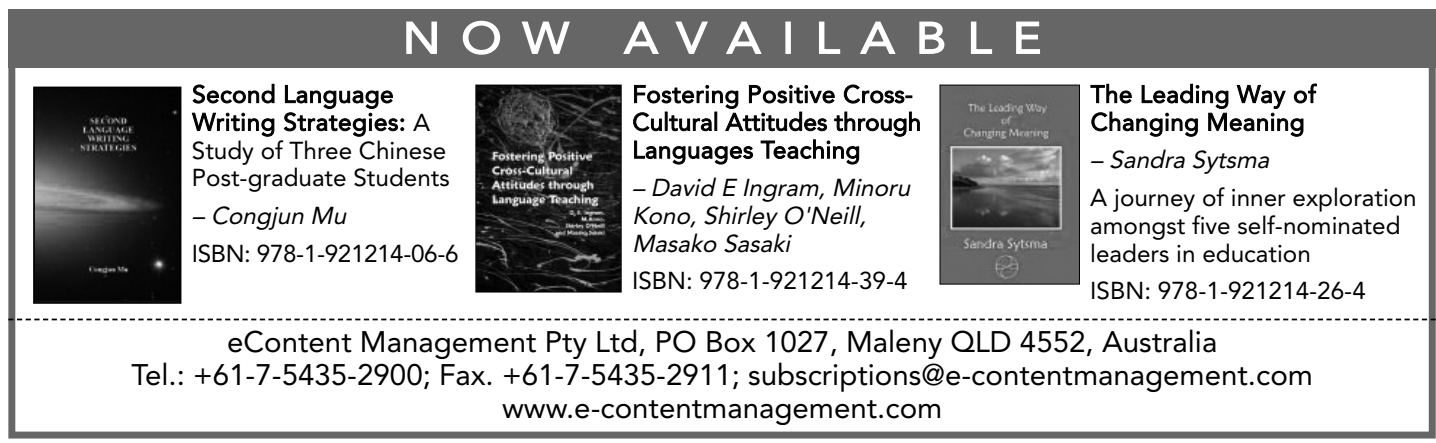

